\title{
The use of new practices for assessment of body condition score
}

\section{El Uso de las nuevas prácticas para la evaluación de la condición corporal}

\author{
Deniz Alic Ural, Ph.D.
}

Adnan Menderes University, Veterinary Faculty, Isikli, Aydin, Turkey. Corresponding: alicdeniz@gmail.com

Received: March 2015; Accepted: September 2015.

\begin{abstract}
Objective. Two body condition scoring systems were compared to those of interpretation of cow's body condition at a local farm located in Aydin region, Turkey. Materials and methods. A total of 50 head Holstein-Friesian cows at $1^{\text {st }}-4^{\text {rd }}$ parity (mid-lactation), raised at a private dairy farm located in Aydin, Turkey was constituted the animal material of the present study. Scores were obtained by use of the primary systems utilized within the US (1-5 scale with 0.25 intervals) and compared to those of Bayer Health Care Animal Health's BCS Cowdition Smartphone App. Results. The overall means of BCS were found as $3.37 \pm 0.068$ and $3.45 \pm 0.060$ for BCS Cowdition and USBCS, respectively. The positive correlation among BCS Cowdition and USBCS systems was found as 0.81 in evaluating body condition $(p<0.01)$. The positive linear relationship $(p<0.001)$ was found between BCS Cowdition and USBCS systems $\left(R^{2}=0.66\right)$. The linear relationship between the latter assessment methods demonstrated that both usual and digital systems tended to scare cows similarly. Conclusions. This comparison represented progress within the understanding of the relationship between these two systems. Moreover, it may be suggested that BCS Cowdition Smartphone App. may be a good alternative for interpretation of BCS.
\end{abstract}

Key words: Body condition score, dairy cattle, new practices (Source: CAB).

\section{RESUMEN}

Objetivo. Dos sistemas de puntuación de la condición corporal se compararon con (el) de la interpretación de la condición corporal de las vacas en una granja local ubicada en la región de Aydin, Turquía. Materiales y métodos. Un total de 50 vacas Holstein Friesian en (su) primera a cuarta parición (a mediados de la lactancia), explotadas en una granja lechera privada situada en Aydin, Turquía constituyó el material animal del presente estudio. Las puntuaciones se obtuvieron mediante el uso de los sistemas primarios utilizados dentro de los EE.UU. (1-5 escala con intervalos de 0.25) y se compararon con (el) de BCS Cowdition Smartphone App de Bayer Health Care Salud Animal. Resultados. Los promedios globales de BCS encontrados fueron de $3.37 \pm 0.08$ y $3.45 \pm 0.060$ para BCS Cowdition y USBCS, respectivamente. La correlación entre BCS sistemas Cowdition y USBCS (para la evaluación de la condición corporal fue de $0.81(p<0.01)$ con un coeficiente de determinación de. Se encontró que la relación lineal positiva $(p<0.001)$ entre BCS Cowdition y sistemas USBCS $\left(R^{2}=0.66\right)$. La relación lineal entre los métodos de evaluación demostró que tanto los sistemas usuales y digitales tienden a calificar a las vacas de manera similar. Conclusiones. Esta comparación constituye un avance en la comprensión de la relación entre estos dos sistemas. Por otra parte, se puede sugerir que a pesar de los cambiarlo por un término adecuado entre evaluadores visuales, BCS Cowdition Smartphone App. Puede ser una buena alternativa para la interpretación de BCS.

Palabras clave: Condición corporal, ganado lechero, nuevas prácticas (Fuente: CAB). 


\section{INTRODUCTION}

Body condition score (BCS) has been recognized as a significant tool for dairy cattle management. Moreover BCS is the foremost method for interpretation of body energy reserves in dairy cows (1-9). It is quite simple and a repeatable system for evaluation of body fat stores $(1,10-$ 14) and a considerable attention has been paid to BCS, in terms of estimating tissue mobilization (15). Also, this system is used to preparation of suitable feed plans and determination of nutritional status of cows in dairy farm (16).

There are some difficulties within the interpretation of BCS systems, through range and variation (2). Furthermore different scoring scales varying from 0 to 4.0 to 5.1 to 4.1 to 5 and 1 to 9 (1). Similarly to US system, the most commonly and probably the foremost scare range applies a scale from 1 to 5 , with 1 being emaciated, 2 thin, 3 average, 4 fat and finally 5 obese in Turkey (17). The latter system was then adopted to a method previously described elsewhere (18), was based entirely upon visual assessment, where as another body condition scoring system involved palpation of the specific body parts, employed in some countries such as UK, Ireland and New Zealand (4).

There is a general consensus regarding benefits of BCS, whereas only a few percentage of farms (solely $5 \%$ ), adopted and explored the feasibility of estimating BCS in US. It should also be stressed that the BCS should be updated on each cattle, reinforcing the cost at the farm (5). The feasibility of BCS interpretation from digital images has been the subject of some prior studies $(1,4)$. Regarding the disperancies among aforementioned studies, the present author decided to perform this study. The present author interest to this subject was aroused following awareness of Bayer Healthcare Animal Health's Innovative BCS Cowdition Smartphone Application, designed for simplification and standardization of the BCS for dairy cows. Therefore the objective of the present work was to better understand and compare the methods of assessing dairy cow BCS, namely visual assessment and digital reports. Hence, the results of this study might have helped researchers and consultants in an attempt to estimate and compare BCS presented from other relevant studies.

\section{MATERIAL AND METHODS}

Animals. Data for the present study were collected from 50 head Holstein-Friesian cows

\section{INTRODUCCIÓN}

La condición corporal (CC) se ha reconocido como una herramienta importante para el manejo de ganado lechero. Además, la CC es el método más importante para la interpretación de las reservas de energía corporal en este ganado (1-9). Es un sistema muy simple y con buena repetibilidad para evaluar las reservas corporales de grasa (1, 10-14); se ha puesto una atención considerable en la CC, en lo que se refiere al cálculo de la movilización de los tejidos (15). Este sistema se utiliza también para la preparación de un plan de alimentación adecuado y para la determinación del estado nutricional de las vacas en la granja lechera (16).

Hay algunas dificultades en la interpretación del sistema de CC, en cuanto al rango y la variación (2). Además, las diferentes escalas de puntuación varían de 0 a 4.0 a 5.1 a 4.1 a 5 y de 1 a 9 (1). En Turquía, de manera similar al sistema utilizado en los Estados Unidos, el más común y probablemente más importante rango de calificación aplica una escala de 1 a 5, siendo 1 demacrado, 2 delgado, 3 promedio, 4 graso y finalmente 5 obeso (17). El último sistema fue aplicado luego a un método descrito anteriormente en otra parte (18) y se basa completamente en la evaluación visual, en tanto que el otro sistema de calificación de la condición corporal empleado en algunos países como el Reino Unido, Irlanda y Nueva Zelanda (4) involucra la palpación de partes específicas del cuerpo.

Existe un consenso general con respecto a los beneficios de la CC, mientras que solo un pequeño porcentaje de las granjas (tan solo el 5\%), adoptó y exploró la viabilidad de la estimación de la CC aprobada en los Estados Unidos. Así que hay que subrayar que la CC debe actualizarse para cada ganado, lo que incrementa el costo en la granja (5).

La viabilidad de la interpretación de la CC a partir de imágenes digitales ha sido objeto de algunos estudios anteriores $(1,4)$. Debido a las discrepancias entre los estudios antes mencionados, este autor decidió realizar este trabajo. El interés del autor en este tema se despertó tras el conocimiento de la aplicación para teléfonos inteligentes BCS Cowdition de Bayer HealthCare Animal Health, diseñada para la simplificación y estandarización de la CC en vacas lecheras. Por consiguiente, el objetivo del presente trabajo fue comprender mejor y comparar los métodos de evaluación de la CC para vacas lecheras, es decir, la evaluación visual y los informes digitales. Por lo tanto, los resultados de este estudio podrían haber ayudado a los investigadores y a los consultores que tratan de estimar y comparar la CC presentada en otros estudios pertinentes. 
at $1^{\text {st }}-4^{\text {rd }}$ parity (mid-lactation), have made one or more birth, without any problems related to reproduction, raised at a private dairy farm located in Aydin, Turkey.

Experimental design. The United States BCS (USBCS) system $(1,18)$ is based completely upon visual estimation by use of a 1-5 scale with 0.25 intervals, as was also used by some researchers (4). After morning milking in farm, BCS data were collected from 16 January 2015 to 16 February 2015 (4 weeks). This BCS were assessed by two experienced researcher (involving the present author, having MS and PhD degrees in Department of Animal Science, Agricultural Faculty) while assessing BCS on visual observing, flowcharts developed by some authors was used (18). Comparatively and as a second method BCS Cowdition Smartphone Application was enhanced. BCS Cowdition is an innovative enhancement from Bayer Healthcare Animal Health's. Assessor with detailed descriptive images of cows having different health conditions, and may be downloaded from the internet at available sources. The program is currently available also in English and Turkish. BCS Cowdition may be used to assess health condition, thus BCS for dairy cows. This innovative smart phone technology programme has a five-step BCS system, lasting after downloading of the cow's photograph, and then was installed on to the smartphone. Afterwards the automated system assesses the BCS.

Briefly, the application is based on Bayer Healthcare Animal Health Division's established 5-step BCS system, allowing the investigator to measure BCS simply by taking photos of each cow individually (Figure 1).

Statistical analysis. Data were analyzed performed by ANOVA using General Linear Model (GLM) procedure of SPSS 18.0 for Windows was used for statistical analysis of data (20). The significance of the differences between groups was compared by Duncan's multiple range tests (21). The relationship between two methods was determined by using Pearson's correlation analyses and the regression models were estimated by using linear regression analysis (20).

\section{RESULTS}

In figure 2 the assessment of a cow was shown with BCS Cowdition system by assessor. Finally at step ( $5^{\text {th }}$ step), the BCS value of cow was found as 3.25 by BCS Cowdition system.

The descriptive statistics of BCS that was estimated according to BCS Cowdition and

\section{MATERIALES Y MÉTODOS}

Animales. Los datos para este estudio se obtuvieron de 50 vacas de raza Holstein-Frisona entre $1^{\mathrm{a}}$ y $4^{\mathrm{a}}$ paridad (lactancia media), con uno o más partos, sin ningún tipo de problemas relacionados con la reproducción, criadas en una granja lechera privada situada en Aydin, Turquía.

Diseño experimental. El sistema CC de los Estados Unidos (USBCS) $(1,18)$ se basa completamente en una valoración visual utilizando una escala de 1 a 5 con intervalos de 0.25 , tal como ha sido utilizado por algunos investigadores (4). Después del ordeño de la mañana en la granja, se recolectaron los datos de CC desde el 16 de enero 2015 al 16 de febrero de 2015 (4 semanas). Estas CC fueron evaluadas por dos investigadores experimentados (incluyendo al autor de este artículo, que tiene una maestría y un doctorado de la Facultad de Agricultura, Departamento de Ciencia Animal), mientras que para la evaluación del grado de CC se utilizaron observaciones visuales y diagramas de flujo desarrollados por algunos autores (18). Comparativamente y como un segundo método, se mejoró la aplicación para teléfonos inteligentes BCS Cowdition. BCS Cowdition es una mejora innovadora de Bayer HealthCare Animal Health. El evaluador que tiene imágenes descriptivas detalladas de las vacas con diferentes condiciones de salud, se puede descargar de Internet de las fuentes disponibles. El programa está disponible actualmente en inglés y turco. La aplicación BCS Cowdition puede ser utilizada para evaluar el estado de salud y, por lo tanto, la CC de las vacas lecheras. Este programa tecnológico innovador para teléfonos inteligentes cuenta con un sistema de CC de cinco pasos después de descargar la fotografía de la vaca, y que luego se instala en el teléfono inteligente. Después, el sistema automatizado evalúa la CC.

En pocas palabras, la aplicación se basa en el sistema de 5 pasos establecido por Bayer HealthCare Animal Health, que le permite al investigador medir la CC simplemente tomando fotos individuales de cada vaca (Figura 1).

Análisis estadístico. Los datos obtenidos se analizaron con ANOVA (análisis de varianza) utilizando el procedimiento del Modelo Lineal Generalizado (MLG) del programa SPSS 18.0 (Statistical Package for the Social Sciences) para Windows que se utilizó en el análisis estadístico de los datos (20). Se comparó la significancia de las diferencias entre los grupos utilizando el método de rango múltiple de Duncan (21). La relación entre los dos métodos se determinó mediante el análisis de correlación de Pearson y los modelos de regresión se evaluaron utilizando el análisis de regresión lineal (20). 


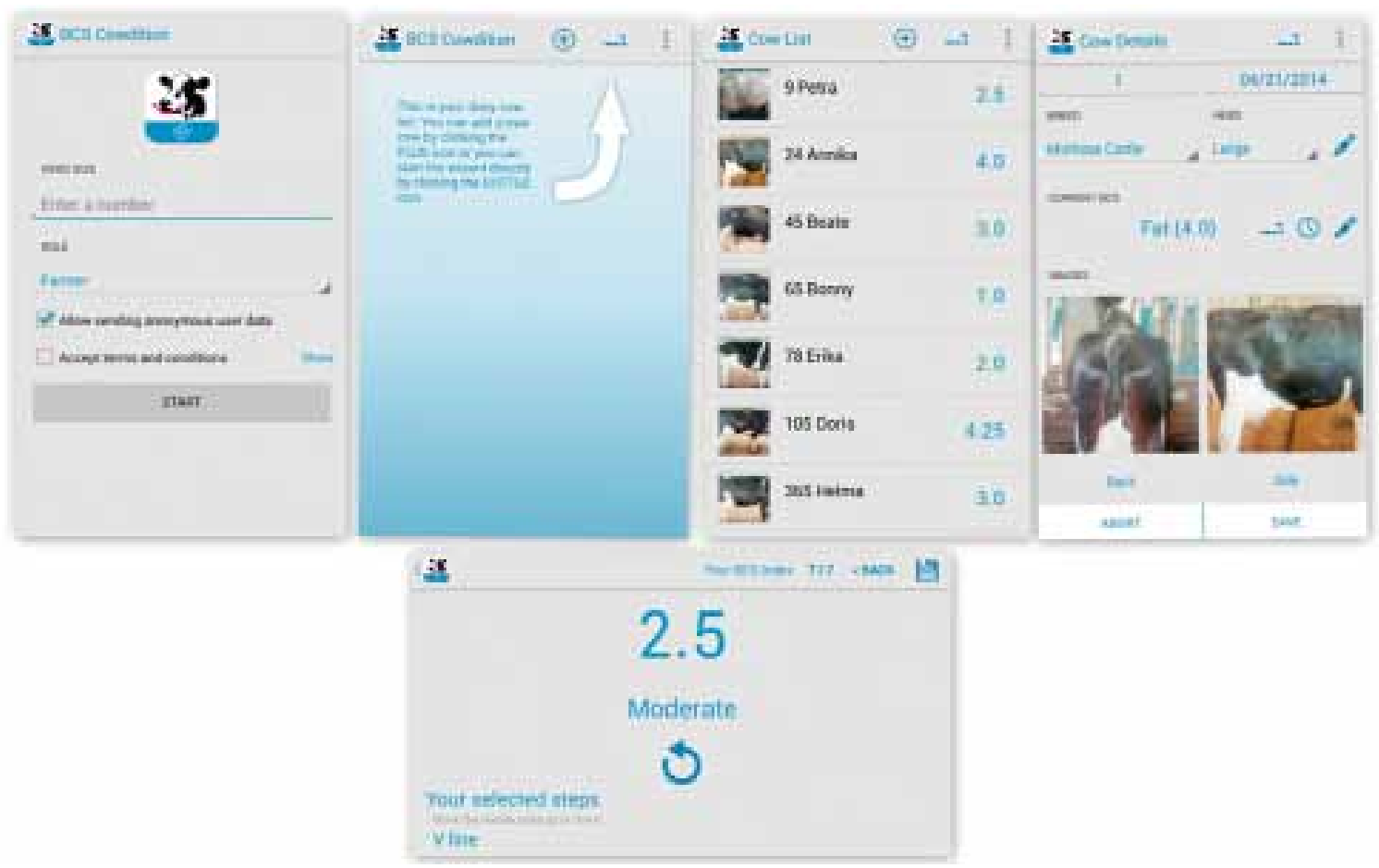

Figure 1. The steps of BCS Cowdition system (19).
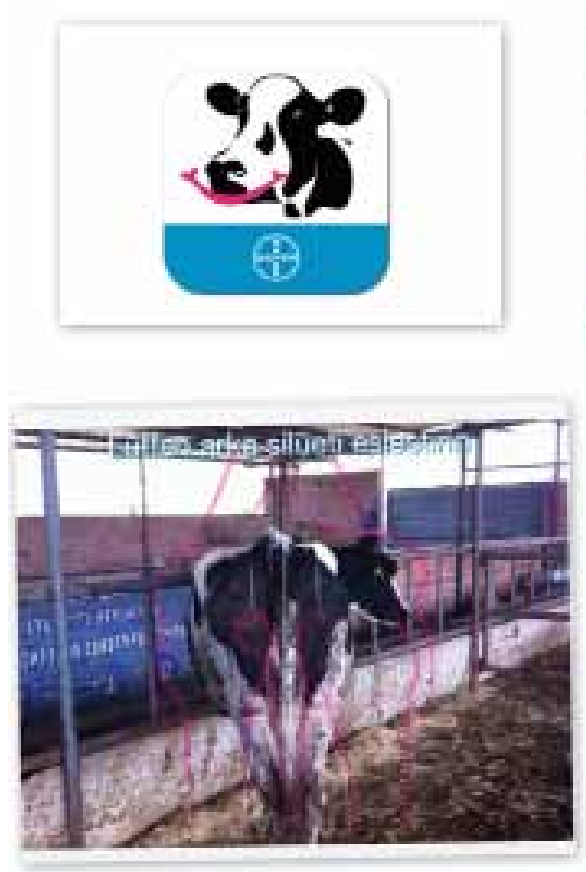
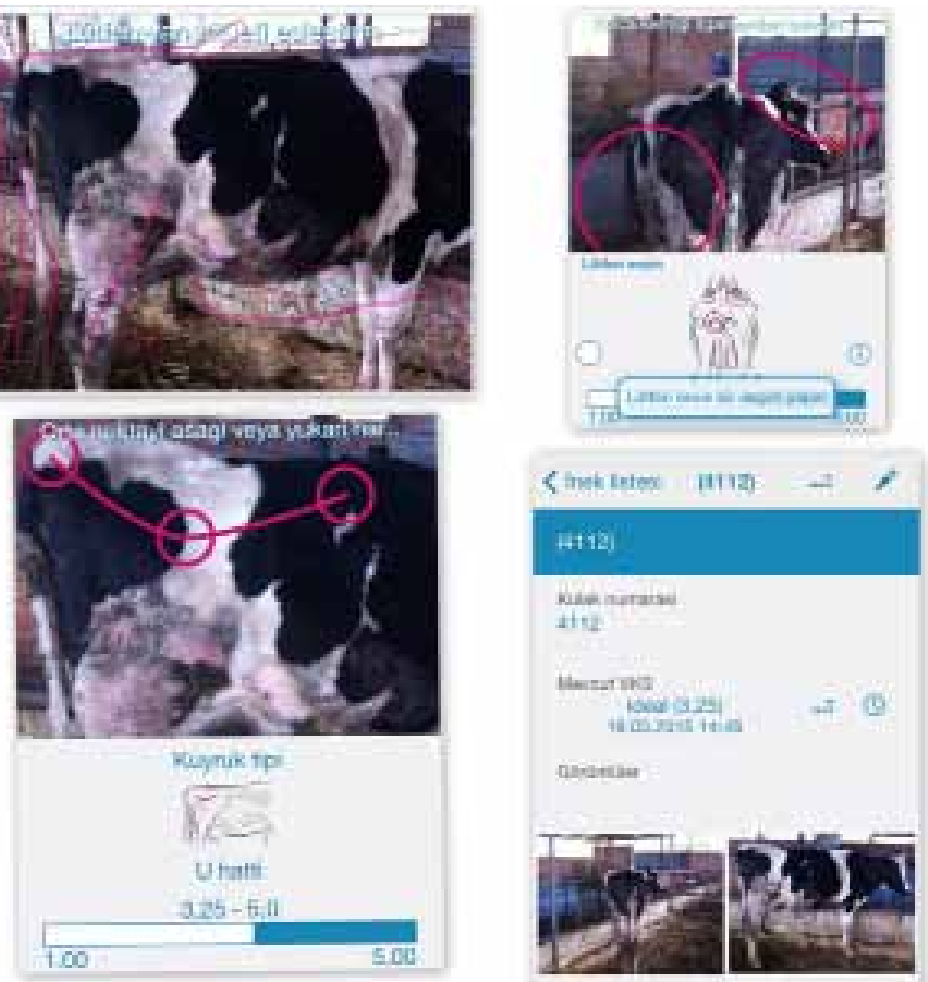

Figure 2. The assessment of a cow with BCS Cowdition. 
USBCS system were given in table 1 . The overall means of BCS were found as $3.37 \pm 0.068$ and $3.45 \pm 0.060$ for BCS Cowdition and USBCS, respectively. The means of BCS for BCS Cowdition ranged from 3.16 to 3.54 , while the means of BCS were ranged from 3.33 to 3.55 in USBCS system (Table 1 ). The effects of parity on BCS were found non-significant in two systems $(p>0.05)$.

The mean differences among BCS were determined 0.08 unit lower in BCS Cowdition than USBCS systems and this differences were found statistically non-significant ( $p>0.05)$.

The positive correlation among BCS Cowdition and USBCS systems was found as 0.81 in evaluating body condition $(p<0.01)$.

The relationship among BCS Cowdition and USBCS systems was shown in figure 3 . The positive linear relationship $(p<0.001)$ was found between two systems (Figure 3 ). The regression equation for estimating COWDITION from USBCS was COWDITION $=0.168+0.928 *$ USBCS $\left(R^{2}=0.66\right)$. The equation for estimating USBCS from COWDITION was USBCS $=1.042+0714 *$ COWDITION $\left(R^{2}=0.66\right)$.

\section{RESULTADOS}

En la figura 2 se muestra la evaluación de una vaca con el sistema de evaluación BCS Cowdition. En el último paso (50 paso), el valor de CC de la vaca que se encontró por medio del sistema BCS Cowdition fue de 3.25 .

La estadística descriptiva para la CC estimada de acuerdo con los sistemas BCS Cowdition y USBCS se presenta en la tabla 1 . La medias generales de $\mathrm{CC}$ que se encontraron fueron de 3.37 \pm 0.068 y $3.45 \pm 0.060$ para BCS Condición y USBCS, respectivamente. Las medias de CC para BCS Cowdition oscilaron entre 3.16 y 3.54 , mientras que las medias de CC estuvieron entre 3.33 y 3.55 en el sistema USBCS (Tabla 1). Se encontró que los efectos de la paridad sobre CC no son significativos en los dos sistemas ( $p>0.05)$.

Se determinó que las diferencias medias entre CC eran 0,08 unidades menores en el sistema BCS Cowdition que en el USBCS y estas diferencias no fueron estadísticamente significativas ( $p>0.05)$.

La correlación positiva entre los sistemas BCS Cowdition y USBCS fue de 0,81 en la medición de la condición corporal $(p<0.01)$.

Table 1. Least square means and standard errors of BCS for two systems

\begin{tabular}{cccc}
\hline Parity & N & BCS Cowdition & USBCS \\
1 & 10 & $3.22 \pm 0.176$ & $3.37 \pm 0.154$ \\
2 & 5 & $3.35 \pm 0.100$ & $3.40 \pm 0.100$ \\
3 & 12 & $3.16 \pm 0.151$ & $3.33 \pm 0.124$ \\
4 & 23 & $3.54 \pm 0.898$ & $3.55 \pm 0.888$ \\
Overall & 50 & $3.37 \pm 0.068$ & $3.45 \pm 0.060$ \\
\hline
\end{tabular}

$*: \mathrm{P}<0.05, * *: \mathrm{P}<0.01$, N.S.: Non-significant

\section{DISCUSSION}

The overall means of BCS Cowdition and USBCS systems for BCS were found as $3.37 \pm 0.068$ and $3.45 \pm 0.060$, respectively. This result was found lower than from findings of Roche et al (22), the same as results of Berry et al (23) and higher from findings of some researchers $(9,18,24-27)$.

BCS become important at different lactation stage (Fresh cows, early lactation, mid-lactation, late lactation and dry period). BCS is generally approximately 3 (5-point scale) or 5 (9-point scale) in mid-lactation stage. If cows occur over-form throughout mid-lactation, BCS is become 3.5 to 4.0 (5-point scale) or 6.0 to 7.0 (9-point scale)(6). The results of this study are accordance with literature.

Some researchers reported that $\mathrm{BCS}<2.5$ and $4.0<$ BCS of cows is largely shown impairment
La relación entre los sistemas BCS Cowdition y USBCS se muestra en la figura 3 . Se encontró una relación lineal positiva $(p<0.001)$ entre los dos sistemas (Figura 3). La ecuación de regresión para la estimación de COWDITION de USBCS fue: COWDITION $=0.168+0.928 *$ USBCS $\left(R^{2}=0.66\right)$. La ecuación para la estimación de USBCS de COWDITION fue: USBCS $=1.042+0.714^{*}$ COWDITION $\left(R^{2}=0.66\right)$.

\section{DISCUSIÓN}

Se encontró que las medias generales de los sistemas BCS Cowdition y USBCS para CC fueron de $3.37 \pm 0.068$ y $3.45 \pm 0.060$ respectivamente. Este resultado fue menor que el encontrado por Roche et al (22), igual a los resultados de Berry et al (23) y superior a los hallazgos de algunos investigadores $(9,18,24-27)$. 


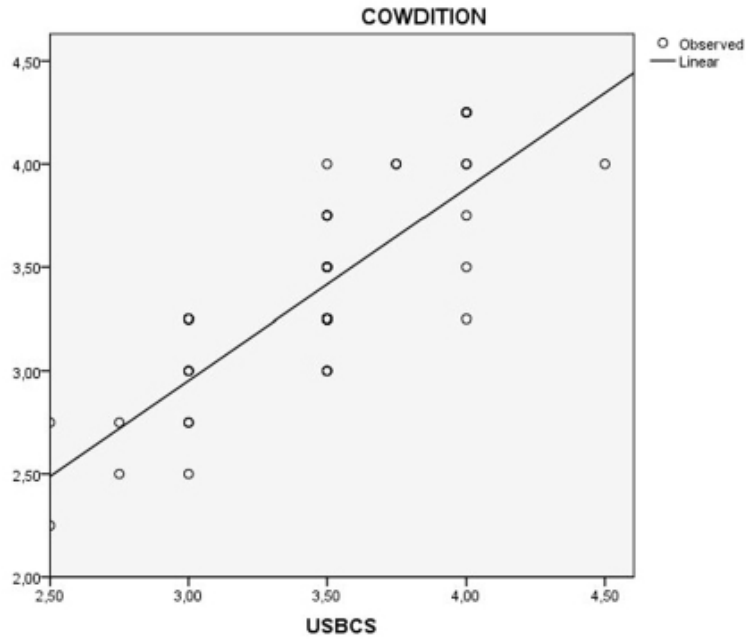

Figure 3. The relationship among methods.

of animal welfare (28). The alterations of BCS may originate from different causes. This may be briefly explained within a proper level of nutrition and a well-designed ration, as was also described previously other authors (29). Moreover, these changes are regard to alteration of body weight of cows and conversion of organism tissues in high productivity (12).

In this study, the effect of parity on BCS was found statistically non-significant $(p>0.05)$. Similarly, Edmonson et al (18) and Berry et al (25) recorded that parity did not affect BCS.

The vast majority of the cows (58\%) were evaluated for BCS at 2.5-3.25 points in this study, similarly to what have been described elsewhere (9). One author reported that most of the cows (42\%) were situated for BCS at 3-4 points. In other study, Estonian Holstein cows were categorized as thin $(28 \%, \mathrm{BCS} \leq 3.0)$, moderate (46\%, BCS 3.25-3.5) and fat $(26 \%, B C S \geq 3.75)(30)$. Some researchers found that $5 \%$ of cows were evaluated BCS $\geq 6.0$ points at calving and $23 \%$ of cows were assessed $\mathrm{BCS} \leq 4.0$ points.

The Pearson correlation coefficient was found as 0.81 in the present study $(p<0.01)$. In a prior study comparing two methods for assessing BCS of dairy cows Scotland, weekly BCS were collected for 3 months. Paired scores $(n=2088)$ between the primary systems utilized in United Kingdom and USA, were moderately correlated $(r=0.75$, $\mathrm{p}<0.0001)(4)$.

The positive linear relationship among two systems declared $\left(R^{2}=0.66\right)$ in the present study is similar to Australian and New Zealand BCS systems $\left(R^{2}=\right.$ 0.61 ) reported by Roche et al (2). This relationship between USBCS and UKBCS systems were found as
La CC se vuelve importante en las diferentes etapas de lactancia (vacas frescas, lactancia temprana, lactancia media, lactancia final y el período seco). Por lo general, la CC es de aproximadamente 3 (en la escala de 5 puntos) o de 5 (en la escala de 9 puntos) en la etapa de la lactancia media. Si las vacas tienen producción mayor durante la lactancia media, la CC alcanza un valor de 3.5 a 4.0 (en la escala de 5 puntos) o de 6.0 a 7.0 (en la escala de 9 puntos) (6). Los resultados de este estudio son consistentes con la bibliografía.

Algunos investigadores informaron que una $\mathrm{CC}<2.5$ y $4.0<\mathrm{CC}$ en las vacas demuestra en gran parte el deterioro del bienestar de los animales (28). Las alteraciones de la CC pueden tener su origen en diferentes causas. Lo anterior se puede explicar brevemente dentro de un nivel adecuado de nutrición y una ración bien diseñada, como lo describieron otros autores previamente (29). Además, estos cambios hacen referencia a la alteración del peso corporal de las vacas y a la conversión de los tejidos del organismo para una alta productividad (12).

En este estudio, se encontró que el efecto de la paridad sobre la CC no era estadísticamente significativo ( $p>0.05)$. Del mismo modo, Edmondson y colaboradores (18) y Berry et al (25) registraron que la paridad no afectó la CC.

La gran mayoría de las vacas (58\%) fueron evaluadas en este estudio con una CC entre 2.5 y 3.25 puntos, de manera similar a lo descrito en otra parte (9). Un autor reportó que la mayor parte de las vacas (42\%) estaban situadas con una CC entre 3 y 4 puntos. En otro estudio, las vacas Holstein Estonia se clasificaron como delgadas $(28 \%$, CC $\leq 3.0)$, moderadas (46\%, CC 3.25 a $3.50)$ y gordas (26\%, CC $\geq 3.75$ ) (30). Algunos investigadores encontraron que el $5 \%$ de las vacas se evaluaron con una $\mathrm{CC} \geq 6.0$ puntos durante el parto y el $23 \%$ de ellas se evaluaron con una CC $\leq 4.0$ puntos.

El coeficiente de correlación de Pearson que se encontró en el presente estudio fue de 0.81 $(p<0.01)$. En un estudio previo realizado en Escocia se compararon los dos métodos de Evaluación del grado de CC de vacas lecheras, se evaluaron los valores de CC semanalmente durante tres meses. Las puntuaciones cotejadas $(n=2088)$ entre el sistema primario utilizado en Reino Unido y en Estados Unidos se correlacionaron moderadamente $(r=0.75, p<0.0001)(4)$.

La relación lineal positiva entre los dos sistemas declarados $\left(R^{2}=0.66\right)$ en el presente estudio es similar a los sistema de CC de Australia y Nueva 
0.56 in another study (4). Also, Isensee et al (14) reported that the $\mathrm{dBCS}$ (dependent $\mathrm{BCS}$ ) was able to explain the BFT (back fat thickness) better than iBCS (independent BCS) $\left(R^{2}=0.67\right)$.

In case of lacking detail, the interpretation of BCS system is not easy. Some researchers were based on photographs with insufficient assessment, and other relevant ones written in lengthy details. All aforementioned factors prevent repetition of the systems (18). New BCS systems should be improved for this reason. Hereby, BCS will be given of beneficial as importance clues in terms of animal health and management practices beneficial. Due to this reasons, widespread distribution of researches in relation to BCS may be used to help interpret results from scores obtained in terms of producer and dairy cattle industry.

The positive linear relationship $(p<0.001)$ was found between BCS Cowdition and USBCS systems $\left(R^{2}=0.66\right)$. The linear relationship between the latter assessment methods demonstrated that both usual and digital systems tended to scare cows similarly. This comparison represented progress within the understanding of the relationship between these two systems. Moreover, it may be suggested that BCS Cowdition Smartphone App. may be a good alternative for interpretation of BCS.

In conclusion subjective BCS from the USBCS and Body Cowdition Smarthphone App. Systems, collected on the same cows in successive 4 weeks, were relatively congruent. Both BCS systems appear to measure body energy reserves in a similar manner, as was also the subject of a prior study assessing UKBCS and USBCS systems (4). Further studies involving more cow population and a larger scale possessing a larger investigation, probably applying this new tool to cows in $1^{\text {st }}$ phase of lactation, and in relation to the corporal condition two weeks before the cow gives birth may be warranted.
Zelanda $\left(R^{2}=0.61\right)$ reportados por Roche et al $(2)$. Se encontró que esta relación entre los sistemas USBCS y UKBCS (CC en el Reino Unido) era de 0.56 en otro estudio (4). De mismo modo, Isensee et al (14) reportaron que la dCC (CC dependiente) puede explicar el BFT (espesor de grasa en la espalda) mejor que la iCC (CC independiente) $\left(R^{2}=0.67\right)$.

A falta de información detallada, la interpretación del sistema de CC no resulta fácil. Algunos investigadores se basaron en fotografías con una evaluación insuficiente y otros en escritos relevantes muy detallados. Todos los factores mencionados anteriormente evitan la repetición de los sistemas (18). Por esta razón, se deben mejorar los nuevos sistemas CC. Es por esto que la CC será de beneficio como un indicio importante de la salud animal y del manejo usando prácticas beneficiosas. Por lo anterior, la distribución generalizada de investigaciones en relación con CC se puede utilizar para ayudar a interpretar los resultados de las puntuaciones obtenidas en términos del productor y de la industria del ganado lechero.

Se encontró una relación lineal positiva $(p<0.001)$ entre los sistemas BCS Cowdition y USBCS $\left(R^{2}=0.66\right)$. La relación lineal entre los últimos métodos de evaluación demostró que los dos sistemas, el habitual y el digital, tienden a calificar a las vacas de manera similar. Esta comparación representó un progreso en la comprensión de la relación entre estos dos sistemas. Se puede sugerir además que la aplicación para teléfonos inteligentes BCS Cowdition puede ser una buena alternativa para la interpretación de la CC.

En conclusión, las CC subjetivas de los sistemas USBCS y de la aplicación para teléfonos inteligentes Cowdition, recolectadas para las mismas vacas durante 4 semanas sucesivas, fueron relativamente congruentes. Ambos sistemas de CC parecen medir las reservas de energía corporal de una manera similar, el cual fue tema de un estudio anterior evaluado por los sistemas UKCC y USBCS (4). Se justifica la realización de otros estudios en una investigación con un mayor alcance donde se incluya una población más grande y una escala mayor, aplicando probablemente esta nueva herramienta a las vacas en su primera etapa de la lactancia y en relación con la condición corporal, dos semanas antes de que la vaca dé a luz. 


\section{REFERENCES}

1. Ferguson JD, Galligan DT, and Thornsen N. Principal descriptors of body condition score in Holstein cows. J Dairy Sci 1994; 77:2695-2703.

2. Roche JR, Dillon PG, Stockdale CR, Baumgard $\mathrm{LH}$, VanBaale MJ. Relationships among international body condition scoring systems. J Dairy Sci 2004; 87(9):3076-3079.

3. Bewley JM, Schutz MM. An interdisciplinary review of body condition scoring for dairy cattle. The Professional Anim Sci 2008; 24(6):507-529.

4. Bewley JM, Boyce RE, Roberts DJ, Coffey MP, Schutz MM. Comparison of two methods of assessing dairy cow body condition score. J Dairy Sci 2010; 77(1):95-98.

5. Battiato S, Farinella GM, Guarnera GC, Puglisi G, Azzaro G, Caccamo M, Licitra G, Ferguson JD. Estimation of cow's body condition score from images. 2010; (access February 5, 2015). URL available in: http://homepages.inf.ed.ac.uk/rbf/ VAIB10PAPERS/gfVAIB2010Final.pdf

6. Klopčič1 M, Hamoen A, Bewley J. Body condition scoring of dairy cows. Republika Slovenija Ministrstvo Za Kmetijstvo, Gozdarstvo in Prehrano 2011, 42p. (access February 5, 2015). URL available in: https:// rodica.bf.uni-lj.si/web/gov/pub/2011_ Klopcic_et_al_Body_condition_of_dairy_ cows.pdf

7. Azzaro G, Caccamo M, Ferguson JD, Battiato S, Farinella GM, Guarnera GC, Puglisi G, Petriglieri R, Licitra G. Objective estimation of body condition score by modeling cow body shape from digital images. J Dairy Sci 2012; 94(4):2126-2137.

8. Thorup VM,Edwards D, Friggens NC. Onfarm estimation of energy balance in dairy cows using only frequent body weight measurements and body condition score. J Dairy Sci 2012; 95(4):1784-1793.

9. Sablik P, Kobak P, Skrzypiec A, Klenowicz $A$, Derezi'nska D. Comparison of body condition scores in Polish Holstein-Friesian Cows of Black-and-White variety managed in different housing systems. Acta Sci Pol Zootech 2014; 13(1):57-66.
10. Yaylak E, Kumlu S. The effects of body condition score and some environmental factors on 305-day milk yield of Holstein cows. Ege Univ Zir Fak Derg 2005; 42(3):55-66.

11. Garnsworthy PC. Body condition score in dairy cows: Targets for production and fertility. Rec Adv Anim Nut 2006; 1: 61-86.

12. Grubić G, Novaković Ž, Aleksić S, Sretenović Lj, Pantelić V, Ostojić-Andrić D. Evaluation of the body condition of high yielding cows. Biotech Anim Husb 2009; 25(1-2):81-91.

13. Roche JR, Friggens NC, Kay JK, Fisher MW, Stattford KJ, Berry DP. Invited review: Body condition score and its association with dairy cow productivity, health, and welfare. J Dairy Sci 2009; 92(12):5769-5801.

14. Isensee $A$, Leiber $F$, Bieber A, Spengler A, Ivemeyer S, Maurer Vi Klocke P. Comparison of a classical with a highly formularized body condition scoring system for dairy cattle. Animal 2014; 8(12):1971-1977.

15. Domecq JJ, Skidmore AL, Lloyd JW, Kaneene JB. Relationship between body condition scores and milk yield in a large dairy herd of high yielding Holstein cows. J Dairy Sci 1997; 80(1):101-112.

16. Garcia A, Hippen A. Feeding dairy cows for body condition score. Progressive Dairyman 2011; (access February 5, 2015). URL available in: http://www.thecattlesite.com/ articles/1512/feeding-dairy-cows-for-bodycondition-score

17. Wildman EE, Jones GM, Wagner PE, Bowman RL. A dairy cow body condition scoring system and its relationship to selected production characteristics. J Dairy Sci 1982; 65(3):495-501.

18. Edmonson AJ, Lean IJ, Weaver LD, Farver T, Webster G. A body condition scoring chart for Holstein dairy cows. J Dairy Sci 1989; 72(1): 68-78.

19. Bayer HealthCare. New BCS Cowdition App. Animal Health 2014, (access February 5, 2015). URL available in: http://animalhealth. bayer.com/ah/5942.0.html 
20. SPSS. SPSS release 18.0.0, Standard version for windows, 2009.

21. Duncan DB. Multiple range and multiple $F$ test. Biometrics 1995; 11:42.

22. Roche JR, Macdonald KA, Burke CR, Lee JM, Berry DP. Associations among body condition score, body weight, and reproductive performance in seasonalcalving dairy cattle. J Dairy Sci 2007; 90(1): 376-391.

23. Berry DP, Buckley F, Dillon P. Body condition score and live-weight effects on milk production in Irish Holstein-Friesian dairy cows. Animal 2007; 1(9):1351-1359.

24. McCarthy S, Berry DP, Dillon $P$, Rath $M$, Horan B. Influence of Holstein-Friesian strain and feed system on body weight and body condition score lactation profiles. J Dairy Sci 2007; 90(4):1859-1869.

25. Berry DP, Buckley F, Dillon P. Relationship between live weight and body condition score in Irish Holstein-Friesian dairy cows. Irish J Agric Food Res 2011; 50, 141-147.
26. Gergovska Z, Mitev Y, Angelova T, Yordanova D, Miteva T. Effect of changes in body condition score on the milk yield of HolsteinFriesian and Brown Swiss cows. Bulg Agric J Sci $2011 ; 17(6)$ : 837-845.

27. Bayram B, Aksakal V, Akbulut O. Effect of the body condition score on some reproduction and milk yield traits of Swedish red and white cows. J Anim Plant Sci 2012; 22(3):545-551.

28. Vasseur E, Gibbons J, Rushen J and de Passillé AM. Development and implementation of a training program to ensure high repeatability of body condition scoring of dairy cows. J Dairy Sci 2013; 96(7): 4725-4737.

29. Alic Ural D. A Study on body condition score of Holstein-Friesian cows raised at Bozdogan. Kocatepe Vet J 2012; 5(2):9-15.

30. Samarütel J, Ling K, Jaakson H, Kaart T, Kärt O. Effect of body condition score at parturition on the production performance, fertility and culling in primiparous Estonian Holstein cows. Vet Zootech 2006; 36(58):69-74. 